\title{
A LINGUAGEM COMO MEDIAÇÃO: uma análise de discurso da expressão midiática "telenovela bíblica"
}

\author{
Lizbeth Kanyat de Novaes ${ }^{1}$
}

\begin{abstract}
Resumo: Apresenta-se uma compreensão conceitual que conecta ontologicamente os estudos de recepção aos estudos de discursos e da linguagem. A proposta central é a compreensão da linguagem como mediação primária entre sujeitos/indivíduos e o mundo. Essa compreensão surge do estudo da relação linguagem e pensamento em Vygotski (2005), Leontiev (2004), Bakhtin (1988), Marx \& Engels (2007) e Schaff (1973,1974); do estudo das mediações em Martín-Barbero (2009); do estudo da proposta teórica da Análise de Discurso de linha francesa em Orlandi (1999) e sua incorporação nas Ciências da Comunicação por Baccega (2003). Conclui-se apresentando uma análise de discurso da expressão "telenovelas bíblicas" para ilustrar como a linguagem medeia não só a mídia mas a nossa compreensão da realidade.
\end{abstract}

Palavras-chave: linguagem e comunicação; mediações; análise de discurso; telenovela.

Abstract: We present a conceptual understanding that connects ontologically the reception studies to discourses studies and language studies. The central proposal is the understanding of language as primary mediation between peolple and the world. This understanding comes from the study of the relationship betwen language and thought in Vygotski (2005), Leontiev (2004), Bakhtin (1988), Marx \& Engels (2007) and Schaff $(1973,1974)$; the study of mediations in Martín-Barbero (2009); the study of the theoretical proposal of French Discourse Analysis in Orlandi (1999) and its incorporation in the Communication Sciences by Baccega (2003). It concludes by presenting a discourse analysis of the expression "biblical telenovelas" to illustrate how language mediates not only the media but our understanding of reality.

Keywords: language and communication; mediations; discourse analysis; telenovelas.

\section{Reflexões ontológicas: linguagem e pensamento}

Jürgen Habermas é considerado por muitos o primeiro estudioso a propor uma teoria exclusiva do campo da Comunicação, a teoria da Ação Comunicativa. Ela se ancora no idealismo subjetivista, uma das abordagens clássicas do processo de conhecimento. Segundo a compreensão idealista, não existe objeto sem sujeito. A realidade passa a ser produção do sujeito. Aqui, a relação que dá existência ao ser humano é a relação com outro sujeito. Esta abordagem dá primazia ao sujeito, sendo ele criador do objeto do conhecimento e não enfatizando a interação entre eles.

Contudo, compreendemos aqui que comunicação é interação e, por isso, nos filiamos à abordagem interacionista. Ela entende que entre o sujeito que conhece e o objeto do

\footnotetext{
${ }^{1}$ Possui graduação em Publicidade e Propaganda e especialização em Docência Universitária pelo Centro Universitário Adventista de São Paulo - UNASP (2009 e 2011). É mestre em Comunicação e Práticas de Consumo pela Escola Superior de Propaganda e Marketing - ESPM (2014), com estágio de pesquisa no Centro Internacional de Estudios Superiores de Comunicación para América Latina (CIESPAL), em Quito - Equador. Atualmente é doutoranda em Comunicação na ECA-USP e coordenadora do curso de Comunicação Social do UNASP.
} 
conhecimento há uma interação. O sujeito não é um mero registrador passivo do objeto, ele exerce um papel ativo no processo de conhecimento. Por outro lado, o objeto mantém sua existência objetiva, independente do sujeito. Ambos polos interagem e isso se dá pela prática social. Para esta abordagem, o indivíduo se constitui na interação social.

Dessa forma, nos apropriamos da compreensão desenvolvida pelo materialismo histórico a respeito da relação ser-objeto. Marx e Engels estudaram a vida social no contexto histórico e material. Eles localizaram o homem no contexto social, redefinindo as relações entre sujeito e objeto, subjetividade e objetividade. Para os autores de A Ideologia Alemã (2007, p. 33), a primeira premissa de toda a existência humana é a de que "os homens têm de estar em condições de viver para poder "fazer história"”. Logo, para viver, os homens precisam, antes de tudo, de se prover de comida, bebida, moradia, vestimenta, etc. Assim, o primeiro ato histórico do homem é "a produção dos meios para a satisfação dessas necessidades, a produção da própria vida material” (Ibid. p, 33). Essa interação, enquanto uso das faculdades físicas e intelectuais no mundo, é uma ação constituinte do ser humano. A constituição da subjetividade não se dá apenas ser-ser, mas também, ser-meio. Para os autores (Ibid. p, 34) essa interação vai se dar através da linguagem. Isto implica em considerar a linguagem como um elemento ontológico do homem.

\footnotetext{
Somente agora, depois de já termos examinado quatro momentos, quatro aspectos das relações históricas originárias, descobrimos que o homem tem também 'consciência'. Mas esta também não é, desde o início, consciência 'pura'. O 'espírito' sofre, desde o início, a maldição de estar 'contaminado' pela matéria, que, aqui, se manifesta sob a forma de camadas de ar em movimento, de sons, em suma, sob a forma de linguagem. A linguagem é tão antiga quanto a consciência - a linguagem é a consciência real, prática, que existe para os outros homens e que, portanto, também existe para mim mesmo; e a linguagem nasce, tal como a consciência, do carecimento, da necessidade de intercâmbio com outros homens.
}

Leontiev também reconhece a relação dialética entre ser e objeto. Em diálogo com Marx, o psicólogo russo assinala que ao mesmo tempo que o homem age sobre a natureza e a modifica, "ele modifica sua própria natureza também e desenvolve as faculdades que nele estão adormecidas" (LEONTIEV, 2004: 80 apud MARX, 1971: 180). Entre essas faculdades, encontra-se a linguagem. Para Leontiev, a linguagem é formada no embate do homem com o mundo. Ele afirma que "a produção da linguagem como da consciência e do pensamento está diretamente misturada na origem à atividade produtiva, à comunicação material dos homens" (LEONTIEV, 2004: 81). Isto é, o desenvolvimento da linguagem não é uma questão 
puramente psíquica, mas também é uma questão social. Essa compreensão é compartilhada pelo psicólogo bielorrusso Lev Semenovitch Vigotsk, o qual explica em Pensamento $e$ Linguagem que "o pensamento verbal não é uma forma de comportamento natural e inata, mas é determinado por um processo histórico-cultural", portanto, "a natureza do próprio desenvolvimento se transforma, do biológico para o sócio-histórico" (2005, p. 63). O filósofo marxista Adam Schaff explica a mesma ideia afirmando que os sujeitos nascem com a faculdade de aprender a falar, mas a palavra se desenvolve no processo social. "Ora, dado que o pensamento conceptual é inconcebível sem a linguagem, em consequência do processo complexo da educação social, o homem não só aprende a falar, mas também a pensar" (SCHAFF, 1994, p. 250).

Para Vigotsky, o crescimento intelectual da criança depende de seu domínio dos meios sociais do pensamento, em outros termos, o domínio da linguagem. "O desenvolvimento do pensamento é determinado pela linguagem, isto é, pelos instrumentos linguísticos do pensamento e pela experiência sócio-cultural da criança” $(2005$, p. 62). O autor não deixa dúvidas sobre a proximidade do seu pensamento com o materialismo histórico. Ele enfatiza que "uma vez admitido o caráter histórico do pensamento verbal, devemos considerá-lo sujeito a todas as premissas do materialismo histórico, que são válidas para qualquer fenômeno histórico na sociedade humana" (Ibid. p. 63).

Portanto, o presente estudo situa-se no paradigma teórico que compreende que o processo de hominização dá-se em contato com o mundo material. Em outras palavras, no embate do ser com o meio. A consciência se desenvolve e se organiza em interdependência com a linguagem, a qual é estudada como um elemento social. Não se trata apenas de sons foneticamente pronunciáveis ou de uma estrutura semântica com normas e regras, os estudos da linguagem são compreendidos como "formulações em que o conhecimento é concebido, produzido e recebido em contextos históricos e culturais específicos" (BRAIT, 2006, p. 10). Esta é também a perspectiva do Círculo de Bakhtin.

O Círculo de Bakhtin busca compreender a linguagem em uso, e não precisamente as estruturas da língua. Bakhtin afirma: "temos em vista o discurso, ou seja, a língua em sua integridade concreta e viva e não a língua como objeto específico da Lingüística" (BRAIT, 2006: 11 apud BAKHTIN, 2002: 181). A nova disciplina é intitulada de Metalinguística, frisando o estudo das questões do uso concreto da linguagem no cotidiano, isto é, das 
questões extralinguísticas. Arisca-se a dizer que a metalinguística estuda a língua real, e não a língua prescrita, normatizada nos manuais de gramática.

Bakhtin (1988) assinala que as bases para uma teoria marxista da criação ideológica estão estreitamente ligadas aos problemas da filosofia da linguagem. "Um produto ideológico faz parte de uma realidade (natural ou social) como todo corpo físico, instrumento de produção ou produto de consumo; mas ao contrario destes, ele também reflete e refrata uma outra realidade, que lhe é exterior" (Ibid. p, 31). Entende-se, portanto, que a realidade é inapreensível de forma 'pura'. Ela manifesta-se por meio dos signos. Dito de outra maneira, a realidade é semiotizada pelos sujeitos e para os sujeitos. Dessa forma, os signos funcionam como mediadores da interação do homem com o mundo.

\section{Linguagem como mediação}

A partir daqui passamos a analisar a linguagem como mediação entre os sujeitos e o mundo. $\mathrm{O}$ conceito de mediações tem sido usado por diversos autores tais como Williams (1979), Thompson (1998), Silverstone (2002), Martín Serrano (1977). No entanto, esta pesquisa se apropriará do conceito de mediações proposto pela teoria das mediações da América Latina, tendo como principal autor Jesus Martín-Barbero (2009). Vale mencionar que a teoria das mediações da América Latina busca desenvolver o conceito usado pelos autores europeus acima citados num esforço de compreender os fenômenos comunicacionais latino-americanos.

Martín-Barbero sugere mudar o lugar de onde se fazem as perguntas. Em vez de realizar a análise a partir dos meios, das mensagens ou da recepção, ele propõe partir das mediações - ênfase que se revela no título da sua obra Dos meios às mediações: comunicação, cultura e hegemonia.

[...] em vez de fazer a pesquisa a partir da análise das lógicas de produção e recepção, para depois procurar suas relações de imbricação ou enfrentamentos, propomos partir das mediações, isto é, dos lugares dos quais provêm as construções que delimitam e configuram a materialidade social e a expressividade cultural da televisão. (MARTÍN-BARBERO, 2009, p. 294).

As mediações, no plural, "é um conceito síntese, que capta a comunicação social a partir de seus nexos, dos lugares a partir dos quais se torna possível identificar a interação entre o espaço da produção e do consumo" (OROFINO, 2006, p. 55). 
A essência do conceito reside em compreender as mediações como os lugares dos quais provêm as construções de sentido. Retomamos, então, a compreensão de que os sentidos, ou dito de outra forma, o pensamento é formado na interação do homem com o mundo. Para Baccega (2003, p. 11) “essa interação vai se dar através da linguagem, sobretudo a verbal. A pesquisadora explica que "é a partir desse 'lugar' que ele [o sujeito] vê, que ele perceber" (op. cit. p, 12). Ao longo da obra Palavra e Discurso (2003), Baccega dá pistas que permitem afirmar que a linguagem é esse lugar de formação de sentidos, elo entre o sujeito e objeto, constituinte do pensamento abstrato e em última instância, mediação da realidade.

O trecho abaixo ilustra a relação entre as mediações de classe, de grupo, de práticas sociais e a linguagem, que aqui propomos considerá-la como mediação primária.

\footnotetext{
Se a alguém ocorre que o homem 'fotografa' a realidade, é bom lembrar que é ele quem escolhe o quê e em que perspectiva fotografar. Também é ele quem vai revelar essas fotos, escurecendo ou clareando este ou aquele ponto, inserindo figuras por inteiro, ou recortando-as [...]. E tudo isso o indivíduo/sujeito faz porque é possuidor de mediações que penetram nele através da linguagem verbal, base de seu pensamento conceptual (BACCEGA, 2003, p. 12).
}

Mais adiante no texto, Baccega (Ibid. p. 31) é mais explícita e assinala que "a mediação entre o homem e a realidade objetiva é exercida pelas linguagens, sobre tudo pela linguagem verbal, pela palavra". A palavra não é o sujeito, não é o objeto, não é ente autônomo. "Ela se manifesta na inter-relação sujeito/objeto, considerados como partes integrantes da realidade. Considerando-se que a mediação entre o sujeito e o objeto se dá pela prática, teremos nesse 'conjunto' a existência da palavra” (Ibid. p. 43). A autora, então, assinala a linguagem como mediação entre o sujeito e o objeto, indicando claramente para a proeminência da linguagem verbal.

\section{Palavra: unidade do pensamento}

O signo da linguagem verbal é a palavra, seja ela falada ou escrita. O signo da linguagem não verbal, podem ser gestos, sons, símbolos, ícones, imagens, etc. Os signos agem no processo de compreensão intersubjetiva. Fora dele perdem seu caráter de signo e não são outra coisa que objetos materiais. Para Schaff (1973), os signos são um elemento indispensável na comunicação humana, a qual só dá-se mediante o pensamento humano. $\mathrm{O}$ pensamento humano, por usa vez, é o pensamento abstrato, o qual se dá, em grande medida, 
pela linguagem verbal. O autor é explícito: "Sustenho que o pensamento especificamente humano é de natureza verbal" (1973, p. 130). O autor esclarece que "a linguagem [verbal] não é o único fator que determina o nosso pensamento; é, contudo, um fator de uma enorme potência de ação e de uma grande importância” (1974, p. 251). Adam Shaff (1974) conclui que a palavra é uma operação do pensamento e a linguagem é um pensamento:

Terminámos a nossa análise da relação da linguagem ao pensamento (cap. II), com as conclusões seguintes: A palavra é sempre uma operação de pensamento, no sentido da experiência que o sujeito faz das significações das palavras, tanto sob a forma de conceitos como sob a forma de representações; a linguagem (de que a palavra é a actualização é, ex definitione, um pensamento in potentia, visto que o sinal linguístico possui, ex definitione, uma significação (Shaff, p. 248).

Bakhtin (1988) também afirma que todo signo é ideológico, possui significado e está sujeito à avaliação. Para Bakhtin (Ibid., p. 32), "um signo não existe apenas como parte de uma realidade; ele também reflete e refrata uma outra", uma vez que ele pode distorcê-la, apreendê-la sob um ponto de vista específico ou ser-lhe fiel. Avaliar ou conhecer um novo signo implica em mobilizar o capital cultural adquirido, que em suma são signos ideológicos já conhecidos. Nas palavras do filósofo, “conhecer um signo consiste em aproximar o signo apreendido de outros signos já conhecidos; em outros termos, a compreensão é uma resposta a um signo por meio de signos" (Ibid, p. 32). Por isso, o signo, afirma-se mais uma vez, é ideológico, é mutante e refrata uma nova realidade, aquela apreendida pelo sujeito.

As linhas anteriores explicam o que Bakhtin chama de dialogismo. Os discursos não se relacionam diretamente com as coisas, mas com outros discursos que lhes dão sentido. Fiorin (2006) explica que o dialogismo é o modo de funcionamento real da linguagem, seu princípio constitutivo e a forma particular da composição do discurso. "Como não existe objeto que não seja cercado, envolto, embebido em discursos, todo discurso dialoga com outros discursos, toda palavra é cercada de outras palavras" (FIORIN, 2006: 167 apud BAKHTIN, 1992: 319). Baccega elucida o anterior com a seguinte metáfora:

Ao nascer, o homem encontra, portanto, uma história em processo. É como se tomasse um trem numa determinada estação. Este trem, que carrega a cultura, está vindo de muitos e muitas estações, já transportou milhões e milhões de pessoas entre as várias estações. São (e/ou foram) pessoas que realizaram, juntas, um número 
incontável de ações, as quais se manifestaram numa pluralidade de significações que as palavras registraram em discursos (BACCEGA, 2007, p. 30, 31).

Por isso, Schaff (1973) afirma que a palavra não é a coisa, é o mapa da coisa é o mapa que nos leva até os as formas como os significados são construídos. Nesse sentido, Lippman (2008) reforça que a definição que temos do mundo é anterior à visão do mundo. Isto quer dizer que existe um mundo mental formando por estereótipos adquiridos pela cultura a partir do qual interpretamos o mundo, buscando referências naquilo que já é conhecido.

$\mathrm{Na}$ maior parte das vezes, não vemos primeiro para depois definir, mas primeiro definirmos e depois vemos. Na grande confusão florida e zunzunante do mundo exterior colhemos o que nossa cultura já definiu para nós, e tendemos a perceber o que colhemos na forma estereotipada, para nós, pela nossa cultura (Lippmann, 1972, p. 151).

\section{Discursos como materialidade de análise}

Para avançar na reflexão proposta, devemos reforçar que o objeto do conhecimento se constitui numa fonte exterior para nossa percepção. Mediante a interação, o sujeito estabelece uma relação particular com o objeto. Ao final do processo, o objeto terá passado de 'algo em si', para 'algo para nós'. O pesquisador pode se debruçar sobre o objeto que o sujeito passou a conhecer através dos discursos que ele pronuncia. Os discursos passam a ser a materialidade para compreender a realidade. A realidade está na linguagem.

\footnotetext{
Ou seja, a realidade é cognoscível e como tal torna-se realidade fabricada pela capacidade humana de atividade. Diferentemente do objeto da lingüística e da pragmática, para a Comunicação a linguagem interessa pelo seu potencial de dar a conhecer como se estabelecem as redes de relações, quais e como circulam os valores e os pontos de vista nos quais se fundamenta a cultura na sociedade contemporânea (FÍGARO, 2009, p. 30).
}

Analisar os sentidos a partir do discurso significa compreender quem é o sujeito e seu lugar social. O centro da relação não está no $e u$ nem no $t u$, mas no espaço discursivo criado entre ambos. Nesse espaço discursivo encontram-se uma infinidade de objetos de pesquisa para o campo da Comunicação. Entre eles o que será explorado neste texto, as identidades. Aqui compreendemos as identidades como construções discursivas que emergem da relação dialética entre sujeitos e o mundo. O indivíduo é compreendido, portanto, como enunciador e enunciatário de discursos identitários. 
Apresentado o dispositivo teórico, passamos a apontar para o objeto de análise: a expressão midiática "telenovela bíblica", usada para divulgar a telenovela $O s$ Dez Mandamentos da Rede Record. Buscaremos a seguir compreender como esse enunciado produz sentidos identitários. Para a Análise de Discurso, a compreensão "procura a explicitação dos processos de significação presentes no texto e permite que se possam 'escutar' outros sentidos que ali estão, compreendendo como eles se constituem" (ORLANDI, 1999, p. 24). Buscaremos apreender as pistas deixadas por esta expressão, pondo em relação o dizer com sua exterioridade e suas condições de produção, considerando que os sentidos encontrados tem a ver com o que é dito ali mas também em outros lugares, assim como o que não é dito, e com o que poderia ser dito e não foi.

\section{Breve análise}

A ficção televisiva (telenovelas, séries e minisséries) é um dos gêneros que ocupa a maior parte da grade de programação das emissoras de TV aberta no Brasil. Diante da presença e oferta massiva de ficção televisiva, desde 2010 a Rede Record tem investido naquilo que se convencionou chamar de um novo gênero de ficção televisiva: a "telenovela bíblica". A audiência dessas produções são objeto de debate e análise tanto por parte de estudiosos do fenômeno religioso quanto por parte de pesquisadores do universo da comunicação. A expressão popular e midiática "telenovelas bíblicas" rotula a oferta de produções ficcionais como um produto novo no cardápio televisivo. Tendo em vista que a expressão "telenovela bíblica” é amplamente usada pela mídia e pela emissora para posicionar suas produções no mercado e diferenciá-las das concorrentes, serão estudados os sentidos que orbitam o termo "telenovela bíblica" e a quais formações discursivas ele remete.

Observa-se nas grades de programação uma oferta variada de ficção no horário nobre da televisão aberta brasileira. As quatro principais emissoras estão empregando receitas diversas para atrair a atenção do telespectador. A produção da TV Globo apoia-se em dramas urbanos e cosmopolitas de ficção televisiva, o SBT investe em um nicho de audiência interessado em remakes de telenovelas focadas nos conflitos amorosos para o público infantojuvenil, a Band aposta no exoticíssimo das telenovelas turcas, e a Record passou a focar em minisséries e telenovelas denominadas "bíblicas". 
Nesse cardápio, o que mais chama a atenção é o sucesso das produções "bíblicas" da Rede Record, atualmente vice-líder de audiência em todo o país com $13 \%$ do share ${ }^{2}$ e mantida pela Igreja Universal do Reino de Deus. A princípio, a proposta de adaptação de histórias bíblicas para o grande público causou estranheza, mas a aposta resultou no maior acerto da emissora. Entre minisséries e séries, a Record já exibiu cinco títulos inéditos desde 2010: A História de Ester (2010), Sansão e Dalila (2011), Rei Davi (2012), José do Egito (2013), Milagres de Jesus (2014/2015). A mais recente produção de ficção televisiva foi $O s$ Dez Mandamentos (2014), considerada a primeira "telenovela bíblica” do país.

O sucesso de Os Dez Mandamentos causa, no mínimo, curiosidade. Por diversas vezes, a telenovela alcançou a liderança do horário nobre durante sua exibição. Na cidade de São Paulo, 29 vezes a "telenovela bíblica" superou a audiência do folhetim concorrente da TV Globo, A Regra do Jogo. Em boletim comemorativo, a Record anunciou inclusive que o folhetim chegou a desbancar o Jornal Nacional ${ }^{3}$. A produção ganhou uma adaptação para o cinema e já está anunciada a segunda temporada da telenovela - o que é bastante incomum pois telenovelas não são dividas em temporadas.

A superprodução da Record foi escrita pela dramaturga evangélica Vivian de Oliveira. Em entrevista ao jornal $\mathrm{O} \mathrm{Dia}^{4}$, a autora comenta que foi criada na Igreja Adventista do Sétimo Dia e, desde a adolescência, quando seus pais deixaram de frequentar a igreja, tem mantido a confessionalidade cristã em diversos movimentos religiosos evangélicos. Atualmente, se identifica como protestante.

Os Dez Mandamentos foi projetada originalmente como uma série de 40 capítulos. Devido à grande aceitação da audiência, foi prolongada para 100, posteriormente para $150 \mathrm{e}$ findou com 176 capítulos e a promessa de uma segunda temporada. Esse panorama leva-nos a pensar porque esse modelo tem apresentado tanto sucesso no Brasil. Afinal de contas, o que pode ter de "bíblica" uma telenovela? Trata-se de um instrumento de evangelização ou mero produto de entretenimento mercadológico?

Para responder essas questões é preciso nos situarmos nos estudos da ficção televisiva. No Brasil, a telenovela tem sido objeto de estudo de dissertações de mestrado e teses de

\footnotetext{
${ }^{2}$ Share refere-se à participação de mercado e corresponde à fatia ou quota de mercado que uma empresa tem no seu segmento. O dado foi extraído do Anuário Obitel 2015.

${ }^{3}$ Boletim comemorativo divulgado na página oficial da emissora na rede social Facebook. Disponível em:https://www.facebook.com/Record.comunicacao/photos/pb.328588080542497.-

2207520000.1449604070./972468366154462/?type=3\&theater. Acesso em: 12 de julho de 2016 .

${ }^{4}$ Disponível em: http://blogs.odia.ig.com.br/leodias/2015/09/11/autora-de-os-dez-mandamentos-eu-nao-gosto-dereligiao/. Acesso em: 12 de julho de 2016.
} 
doutorado no campo da Comunicação desde a década de 1970. Em 1992, a Universidade de São Paulo fundou o Centro de Estudos de Telenovelas (CETVN), do qual surgiu o Observatório Íbero-americano de Ficção Televisiva (Obitel). Este observatório congrega pesquisadores de doze países que investigam a produção, circulação e recepção de ficção televisiva em seus respectivos territórios. Fruto desse trabalho são os Anuários Obitel, disponíveis online ${ }^{5}$. Além disso, o observatório promove eventos que recebem dramaturgos, produtores e executivos das principais emissoras íbero-americanas para discutir o presente e o futuro da ficção televisiva.

As pesquisas do CETVN e do Obitel têm se ancorado na corrente teórica dos estudos de recepção, que permitem investigar os significados que as audiências efetivamente elaboram sobre as mensagens dos diversos meios de comunicação. Considera-se que o polo da recepção não é passivo, mas sim trata-se de sujeitos ativos, que negociam e ressignificam aquilo que lhes é proposto. Os estudos de recepção consideram que o entretenimento consumido pelas pessoas no cotidiano é um importante canal de contato com os sujeitos e suas subjetividades. As histórias, consumidas em momentos de descontração, podem tocar os sentimentos de forma mais direta do que uma aula na faculdade, um discurso no palanque ou, algumas vezes, mais do que um sermão na igreja. Ao assistirmos produtos ficcionais passamos a sentir o que os personagens sentem, nos identificarmos com as suas histórias, torcemos pelos encontros, choramos pelos desencontros, rimos e pensamos sobre o que nos é colocado pelo televisor. A telenovela, portanto, não deve ser considerada como simples lazer, bobagem ou coisa sem importância.

[...] na televisão não existe nada que possa definir-se como um texto inocente, nenhum programa que não mereça ser objeto de cuidadosa atenção, nenhum programa que possa pretender que só oferece entretenimento e que não transmite nenhuma mensagem sobre a sociedade (MORLEY, 1996, p. 120, tradução nossa).

Logo, a telenovela é um elemento da cultura popular que tem sido inserido diariamente no cotidiano familiar e, por isso, marca a linguagem com seus bordões, altera o consumo com suas modas, roupas e acessórios e influencia o pensamento com as ideias por ela apresentadas. Tudo isso não é novidade, entretanto. As emissora de televisão sabem muito bem que a ficção atrai o público. Não é por acaso que o horário nobre da televisão aberta é composto principalmente de programas ficcionais (mais especificamente, telenovelas). Em

\footnotetext{
${ }^{5}$ Anuários disponíveis para download no www.obitel.net.
} 
uma análise da oferta televisiva, não se deve ignorar que tudo o que é exibido responde aos interesses da emissora. $\mathrm{O}$ mundo que nos é apresentado por meio da televisão é um mundo editado, um recorte da realidade e, quando se trata de ficção, é ainda uma realidade construída.

Numa analise do contexto de produção (ORLANDI, 1999), é importante assinalar que a Rede Record é uma emissora comercial. Sua grade de programação, como qualquer outra emissora desse porte, visa o lucro. As telenovelas, séries e minisséries são produzidas para entreter, com o objetivo de magnetizar o maior número de espectadores possível. Elas não tem o propósito de evangelizar. A autora de Os Dez Mandamentos, em entrevista ao UOL, afirma que "a TV brasileira precisa de boas ideias, independente de ser bíblica ou não. Acontece que as bíblicas geralmente são muito boas e o Brasil está descobrindo isso agora. Hollywood [EUA] já vinha explorando isso" ". As minisséries, séries e telenovelas da Record foram popularizadas pela grande mídia como "bíblicas", contudo, para a própria Vivian, assim como para os estudiosos de ficção do Obitel e do CETVN, elas são consideradas telenovelas históricas. As obras de ficção não são classificadas pelas suas temáticas. É uma imprecisão chamar de "bíblica" a uma telenovela que foi inspirada numa história bíblica, assim como não se chama de "literária" a uma telenovela que é baseada num clássico da literatura. Contudo, existem sim diversas nomenclaturas que classificam a ficção televisiva. Apresenta-se a seguir as mais relevantes para esta análise.

Pela sua temporalidade, a ficção é classificada pelo Obitel em: presente (histórias ambientadas na contemporaneidade), históricas (quando trata de acontecimentos históricos) e de época (histórias ambientadas no passado). Por outro lado, as telenovelas são classificadas por suas caraterísticas narrativas e estilísticas em dois grandes modelos: o tradicional e o moderno (2011).

O modelo tradicional que neutraliza as referências de lugar e tempo, aposta na cenografia, no luxo da decoração e em figurinos pomposos. Os conflitos principais são os amorosos e de parentesco, a estrutura dos estratos sociais é cruamente maniqueísta, colocando em cena paixões e sentimentos primordiais. O seu principal expoente são os melodramas mexicanos. Já o Brasil inaugurou o modelo moderno, que sem romper com o esquema melodramático, incorporou o realismo. São telenovelas cuja narrativa enfocam o cotidiano urbano e muitas vezes fazem referências à acontecimentos históricos reais. Elas se baseiam

\footnotetext{
${ }^{6}$ Disponível em: https://www.youtube.com/watch?v=18kHWSlqPWk. Acesso em 12 de julho de 2016.
} 
nas matrizes culturais do país, e dão espaço à complexidade e à ambiguidade dos sentimentos, explorando recursos vindos do cinema. Seu principal expoente são as chamadas "novelas das oito" ou "das dez" na TV Globo. Naturalmente, o público reconhece esses modelos e eles se tornam critério decisivo na hora de escolher qual telenovela acompanhar. Enquanto a TV Globo é uma clara expoente do modelo moderno ao adotar temas ousados e estratégias estéticas vanguardistas a fim de alcançar um público que flerta com os seriados norteamericanos, a Rede Record está direcionando seu negócio para um público mais conservador, religioso e acostumado com o melodrama tradicional mexicano.

A telenovela é uma obra ficcional do gênero melodrama que, por sua vez, tem por eixo central quatro sentimentos básicos: medo, entusiasmo, dor e riso. Eles correspondem a quatro tipo de situações que são, ao mesmo tempo, sensações: terríveis, excitantes, ternas e burlescas. Essas situações, por sua vez, são vividas por quatro personagens: o traidor, o justiceiro, a vítima, e o bobo (MARTÍN-BARBERO, 2009). Por isso, é previsível encontrar em uma telenovela, embora seja uma adaptação de uma história bíblica, dramas familiares, vingança, traição, intriga, superação, amores proibidos, entre outros recursos narrativos que são caraterísticos de qualquer melodrama. Assim, Os Dez Mandamentos, como qualquer outra telenovela, fala da compaixão humana, das inseguranças, das paixões proibidas, das ambições, das injustiças e dos conflitos.

O telespectador perspicaz perceberá que as adaptações de histórias bíblicas para filmes, séries ou telenovelas não buscam ser fieis ao texto sagrado. Antes, procuram contar novas histórias a partir das narrativas das Escrituras. Há duas caraterísticas do formato telenovela que ajudam a entender isso. A primeira característica da telenovela é uma obra de longa duração: em média, as telenovelas tem 170 capítulos. Para sustentar a história de Moisés por oito meses, a autora precisou explorar as brechas que o texto bíblico deixava. Ela precisou atribuir personalidade e complexidade a personagens brevemente descritos na Bíblia, além de conferir-lhes uma história de vida e de situá-los em um contexto de relações sociais (família, amizades, trabalho, vizinhança). Ademais, foi também imperativa a necessidade da criação de novos personagens, núcleos, conflitos e histórias não existentes no Pentateuco, o que representou um elenco de 110 atores. Assim como a outras produções de temática bíblica da emissora, a telenovela em questão não foi um programa de televangelismo ou um documentário sobre uma história bíblica. Trata-se, acima de tudo, de um produto televisivo que almeja entreter e agradar ao maior número de telespectadores. Em entrevista, a autora 
afirma que "a Record descobriu um nicho de mercado e que está dando certo, enquanto muita gente acreditava que não daria certo. Fui ganhando experiência e o que mais quero é continuar nesse ramo [temas bíblicos] até que se esgote" 7 .

Aqui vale mencionar uma segunda caraterística do formato ficcional telenovela: elas são obras abertas. Isso quer dizer que as telenovelas são escritas e gravadas enquanto são exibidas. Na estreia de uma telenovela há em média cerca de 20 capítulos gravados, o restante da história é desenvolvida sob influência da reação do público. Personagens que tiveram aceitação ganham mais protagonismo, ao passo que personagens que são rejeitados pelo público perdem tempo de cena. Assim, as personagens ganham contornos que buscam o engajamento do público, embora estes se distanciem do texto bíblico, uma vez que a finalidade primária de uma emissora comercial é alavancar a audiência.

No caso da telenovela $O s$ Dez Mandamentos há três elementos que, para esta análise, explicam o seu sucesso: a proximidade cultural, o interesse pelo exótico e a proximidade de valor (STRAUBHAAR , 2013). A proximidade cultural acontece quando uma obra apresenta dramas humanos atemporais e arquétipos universais. Como é o caso da história do varão valoroso e justiceiro (Moisés), a luta heroica da mãe para reencontrar o filho (Joquebede), etc. Em qualquer época, em qualquer local, as pessoas podem relacionar essas tramas universais, retratadas na telenovela, com a situações vivenciadas. Outro apelo mobilizado pela produção da Record é o destaque ao exótico. Esse recurso é também muito utilizado pela autora global Glória Perez, criadora de uma série de sucessos de audiência ambientados em culturas exóticas - Caminho das Índias (Índia), O Clone (Marrocos), Salve Jorge (Turquia). O exótico chama a atenção porque, via de regra, o cotidiano, o familiar e local podem ser entediantes. Daí o fato da trama que ocorre no Egito, com um figurino exuberante, chame a atenção do telespectador.

Por fim, a proximidade de valor tem que ver com o fato da primeira "telenovela bíblica" ter alcançado o público evangélico, cada vez mais presente e influente na demografia brasileira $^{8}$. O aumento dos evangélicos no Brasil fortaleceu a indústria gospel, provocando a criação de uma cultura evangélica de consumo ${ }^{9}$. Está havendo um revestimento sacro de todo e qualquer produto cultural: há o rock "cristão", a literatura "gospel", a moda feminina

\footnotetext{
${ }^{7}$ Disponível em: https://www.youtube.com/watch?v=18kHWSlqPWk. Acesso em: 12 de julho de 2016.

${ }^{8}$ Para mais informações sobre a configuração demográfica religiosa brasileira, ver TEIXEIRA, Faustino; MENEZES, Renata (orgs.). Religiões em movimento: o Censo de 2010. Petrópolis, RJ: Vozes, 2013.

${ }^{9}$ Ver CUNHA, Magali. A explosão gospel: um olhar das ciências humanas sobre o cenário evangélico no Brasil. Rio de Janeiro: Mauad/Instituto Mysterium, 2007.
} 
"evangélica" e, também, a telenovela "bíblica". Uma vez que a maioria dos movimentos religiosos evangélicos recomenda a seus membros a abstinência de ficção televisiva, em particular de telenovelas, a Record veio "resolver" o impasse do público crente ávido por entretenimento, revestindo o clássico melodrama de roupagem sacra. Assim, cria-se proximidade de valor entre o público cristão e o produto ficcional. Ou seja, o público reconhece na obra elementos que sua religião valoriza, como é o contemplar de histórias bíblicas. Dessa forma, o telespectador justifica sua escolha pelos programas que retratam histórias do livro sagrado, podendo agora assistir os dramalhões adjetivados de "bíblicos".

Percebemos, portanto, a conexão entre duas formações discursivas (ORLANDI, 1999): o discurso do entretenimento e o discurso religioso. Por um lado, está a "telenovela", na formação discursiva do entretenimento, como uma atração proibida pelo discurso religioso. Contudo, soma-se a ela o adjetivo "bíblico", o que provoca um deslizamento de valores. A violência, a traição, a vingança, elementos da narrativa dramatúrgica que antes eram razões para desprezar a telenovela, passam a ser tolerados. A adjetivação "batiza" a ficção e faz com que tudo o que ela exibe seja sacralizado. Pela predicação do termo telenovela, percebemos a polissemia (ORLANDI, p. 34), o deslocamento e ruptura do processo de significação que antes condenava a telenovela, dando passo à aceitação da mesma.

Pela predicação do termo telenovela, percebemos a polissemia, que para Orlandi (1999, p. 34) é o deslocamento e ruptura de significados. A adição do adjetivo "bíblica" à palavra telenovela para denominar a ficção televisiva de longa duração inspirada em histórias do livro sagrado cristão provoca uma ruptura com os significados dados anteriormente à telenovela. Antes a ficção era um tipo de entretenimento impróprio para o cristão, por ela trazer à tona o que há de mais desprezível no ser humano (traição, vingança, ódio). Porém, a construção de significados sobre o que se denomina de "telenovela bíblica" passa por um caminho diferente, conforme apresentado na análise. A identidade religiosa é mobilizada no processo de recepção fazendo com que a proximidade de valor seja um forte elemento na construção de significados. Isto somado a outros fatores não explorados no texto, como a pouca criticidade na leitura da mídia, parece levar os telespectadores à um senso de que a esse tipo de telenovela é próprio assistir.

\section{Considerações}


No presente estudo, apresentamos a comunicação como a inter-relação entre indivíduos/sujeitos dialogicamente constituídos. Essa premissa filia-se na abordagem interacionista do processo do conhecimento - a qual se concentra na interação existente entre o sujeito e o objeto. De acordo com essa abordagem, o objeto mantém sua existência objetiva, independente do sujeito. E por sua vez, o sujeito é um indivíduo concreto, que se constitui na interação social. É no "estar no mundo" que o sujeito interage com o objeto do conhecimento. Essa interação dá-se em primeira instância através da linguagem, sobretudo, da linguagem verbal. Damos primazia à linguagem verbal porque compreende-se que ela medeia as outras mediações. A linguagem é materialidade através da qual pode-se estudar a realidade. A Análise de Discurso (AD) de linha francesa revela-se, portanto, uma método útil para estudar os discursos resultados da interação do homem com o mundo. A AD procura compreender a língua fazendo sentido, enquanto trabalho simbólico, parte do trabalho social geral, constitutivo do homem e da sua história. Percebemos, portanto, que para compreender a comunicação é importante o estudo do lugar onde se formam os sentidos, isto é, o estudo da relação cultura/linguagem/pensamento. A aplicação empírica destas reflexões se deu na análise da expressão midiática telenovela bíblica usada para apresentar produções de ficção seriada que representam histórias do livro sagrada cristão. A problemática apresentada apontou à telenovela como um produto cultural costumeiramente alvo de críticas e considerado desfavorável para a membresia de muitas comunidades evangélicas. Contudo, a predicação do palavra telenovela provoca um deslizamento de sentidos que, em conjunto com outros fatores, altera a percepção do produto. Apesar de ser uma obra correspondente às estruturas clássicas do melodrama, a telenovela bíblica Os Dez Mandamentos, torna-se um produto apto para o consumo do cristão. A reflexão aqui tecida, portanto, assinala a que a materialidade da realidade passa pela linguagem e, portanto, por um trabalho de construção ideológica.

\section{Referências}

BACCEGA, M. A. Palavra e discurso. História e literatura. São Paulo: Ática, 2003. 
BAKHTIN, M. (VOLOSHINOV) Marxismo e filosofia da linguagem. São Paulo: Hucitec, 1988.

BRAIT, B. (org.). Bakhtin. Outros conceitos-chave. São Paulo: Contexto, 2006.

FÍGARO, R. A. Comunicação e Trabalho: binômio teórico produtivo para as pesquisas de recepção. Mediaciones Sociales. Revista de Ciencias Sociales y de la Comunicación, n ${ }^{\circ}$, primer semestre de 2009: 23-49.

FIORIN, J. L. Interdiscursividade e Intertextualidade. In.: BRAIT, Beth (org.). Bakhtin. Outros conceitos-chave. São Paulo: Contexto, 2006.

JACKS, N. (Org.). Meios e Audiências II: A consolidação dos estudos de recepção no Brasil. Porto Alegre: Editora Sulina, 2014.

LEONTIEV, A. O desenvolvimento do psiquismo. São Paulo: Centauro, 2004.

MARTÍN SERRANO, M. La mediación social. Madri: Akal, 1977.

MARTÍN-BARBERO, J. Dos meios às mediações: comunicação, cultura e hegemonia. Rio de Janeiro: Editora UFRJ, 2009.

SENAC, 2001.

Os exercícios do ver: hegemonia audiovisual e ficção televisiva. São Paulo:

MARX, K, ENGELS, F. A ideologia alemã. São Paulo; Boitempo, 2007.

MORLEY, D. Televisión, audiencias y estudios culturales. Buenos Aires: Amorrortu editores, 1996.

ORLANDI, E. Análise de Discurso: princípios e procedimentos. Campinas: Pontes, 1999.

OROFINO, M. I. Mediações na produção de TV um estudo sobre o Auto da Compadecida. Porto Alegre: EDIPUCRS, 2006.

SCHAFF, A. Lenguaje y acción humana. In: SCHAFF, Adam. Ensayos sobre filosofía del lenguaje. Barcelona: Ariel, 1973. p. 124-145

SCHAFF, A. Linguagem e conhecimento. Coimbra: Almedina, 1974. p 247-268.

SILVERSTONE, R. Por que estudar a mídia? São Paulo: Edições Loyola, 2002.

STRAUBHAAR, J. Sedimentada, híbrida e múltipla? A nova geografia cultural das identidades. MATRIZes, São Paulo, v. 7, n. 1, p. 59-93, jan./jul. 2013.

THOMPSON, J. A mídia e a modernidade: uma teoria social da mídia. Petrópolis: Vozes, 1998.

VYGOTSKI, L. S. Pensamento e linguagem. São Paulo: Martins Fontes, 2005.

WILLIAMS, R. Marxismo e literatura. Rio de Janeiro: Zahar, 1979. 
revista do programa de pós-graduação em comunicação social faculdade de comunicação e artes da PUC Minas 